\title{
Aplikasi Structural Equation Modelling (SEM) pada Pola Kepemimpinan TNI AL
}

\author{
Nugroho Adijanto ${ }^{1^{*}}$, Judijanto ${ }^{1}$, Nentin Feriyanti ${ }^{1}$ \\ ${ }^{1}$ Sekolah Staf dan Komando TNI AL \\ JI. Jalan Ciledug Raya No 2 Cipulir Kebayoran Lama 12230 DKI Jakarta \\ *dewabisma007@gmail.com \\ DOI: https://doi.org/10.21107/rekayasa.v14i3.11018
}

\begin{abstract}
In the era of globalization which is full of change and competition, an organization must show the best performance in order to survive through managing its resources through the right leadership. One indicator of the success of a leadership pattern is the creation of subordinate job satisfaction. With job satisfaction, a subordinate will be able to bring out his best abilities for the benefit of the organization. However, the existence of discipline enforcement efforts will affect the role of leadership patterns in realizing job satisfaction of subordinates in the organization. The purpose of this study is to identify the effect of leadership patterns on the job satisfaction of subordinates, and to identify this effect with the enforcement of discipline as a moderator. In this study, the types of leadership patterns observed were transformational leadership patterns, transactional leadership patterns, visionary leadership patterns and synergistic leadership patterns. Research data obtained from questionnaires distributed to respondents totaling 209 personnel who meet the requirements, then data processing is carried out using the structural equation modeling (SEM) method. The results of the SEM calculation show that without a moderating variable, discipline enforcement efforts, transformational leadership patterns and synergistic leadership patterns affect the job satisfaction of subordinates. Meanwhile, with efforts to enforce discipline, the transactional leadership pattern variable also has an influence on the job satisfaction of subordinates.
\end{abstract}

Key words : leadership pattern, job satisfaction, discipline enforcement

\section{PENDAHULUAN}

Era globalisasi menuntut sebuah organisasi untuk berkembang dan menyesuaikan diri dengan lingkungannya agar tetap bertahan berhadapan dengan perubahan, perkembangan dan kemajuan jaman dari segala lini kehidupan. Kompleksitas masalah dalam organisasi mengakibatkan kebutuhan organisasi akan pemimpin yang memiliki kualitas tertentu. Keberhasilan tugas organisasi tidak terlepas dari performansi kerja anggota organisasi baik pimpinan maupun bawahan. Performansi kerja berhubungan dengan kepuasan kerja. Terciptanya kepuasan kerja akan meningkatkan performansi kerja. Performansi kerja yang baik akan mendukung keberhasilan pelaksanaan tugas pokok. Namun dalam dunia kepuasan kerja sering kali terabaikan terutama jika dikaitkan dengan tuntutan tugas. Kondisi kepuasan kerja dipengaruhi oleh beberapa faktor, yaitu pola kepemimpinan, kondisi pekerjaan, hubungan antar

Article History:

Received: June, 30 ${ }^{\text {th }}$ 2021; Accepted: November, 17 2021 Rekayasa ISSN: $2502-5325$ has been Accredited by Ristekdikti (Arjuna) Decree: No. 23/E/KPT/2019 August 8th, 2019 effective until 2023 rekan kerja serta imbalan (Smith, Kendal \& Hullin, 1989 dalam Budikusumah 2001).

Selain dipengaruhi oleh pola kepemimpinan kepuasan kerja juga dipengaruhi oleh disiplin. Sesuai dengan apa yang dikatakan Timpe (1999), kepemimpinan itu adalah seni dan bukan keterampilan atau ilmu. Itulah sebabnya pemimpin yang berbeda sering mengambil pendekatan yang juga berbeda terhadap tanggung jawab mereka. sehingga bawahan memerlukan waktu untuk menyesuaikan diri dengan pola kepemimpinan yang baru. Hal ini tentunya cenderung mempengaruhi kinerja bawahan itu sendiri, pelaksanaan tugas pokok dan pencapaian tujuan organisasi, bahkan dapat memberikan hambatan bagi tercapainya kepuasan kerja bawahan tersebut. Permasalahan yang akan diteliti adalah bagaimana pengaruh pola kepemimpinan terhadap kepuasan kerja bawahan dilingkungan organisasi, bagaimana

\section{Cite this as:}

Adijanto, N., Judijanto \& Feriyanti, N. (2021). Aplikasi Structural Equation Modelling (SEM) pada Pola Kepemimpinan TNI AL . Rekayasa 14 (3). 401-406. doi: https://doi.org/10.21107/rekayasa.v14i3.11018. 
pengaruh pola kepemimpinan terhadap kepuasan kerja bawahan setelah dimoderasi oleh upaya penegakan disiplin dan bagaimana menganalisis pola kepemimpinan yang sesuai untuk diterapkan dalam organisasi sehubungan dengan adanya upaya penegakkan disiplin. Dimana tujuan dari penelitian ini adalah menganalisis pengaruh pola kepemimpinan terhadap kepuasan kerja bawahan setelah dimoderasi oleh upaya penegakan disiplin.

Kepuasan kerja adalah suatu sikap umum seorang individu terhadap pekerjaannya (Robbins, 2003). Faktor kepuasan kerja terdapat tiga dimensi yang mempengaruhi kepuasan kerja. Pertama, kepuasan kerja merupakan respon emosional terhadap situasi kerja. Kedua, kepuasan kerja seringkali ditentukan oleh seberapa besar hasil yang diperoleh dapat memenuhi atau melebihi apa yang diharapkan. Ketiga, kepuasan kerja menggambarkan beberapa sikap yang saling berhubungan. Selanjutnya (Smith, Organ, \& Near, 1983) berpendapat bahwa terdapat lima dimensi kerja yang menunjukkan karakteristik kerja yang paling penting yang dapat mempengaruhi apakah pekerja memilki perasaan yang positif atau tidak terhadap pekerjaannya, kelima dimensi tersebut adalah : work itself, pay, promotion opportunities, quality of supervision, relationship with co-workers. Sedangkan menurut (Hayati \& Faisal, 2018) menyatakan bahwa kepuasan kerja bergantung pada karakteristik pekerjaan dan karakteristik pekerja itu sendiri.

Faktor-faktor yang mempengaruhi kepuasan kerja adalah compensation, supervision, work itself, co-workers, job security, advancement opportunity. Menurut (Robbins \& Judge, 2013) menyatakan bahwa ada empat faktor yang mendorong kepuasan kerja. Keempat faktor tersebut adalah Kerja yang secara mental menantang, Ganjaran yang pantas, Kondisi kerja yang mendukung, Rekan kerja yang mendukung. Adapun efek dari kepuasan kerja terdapat 3 hal yakni produktivitas, keabsenan, dan pengunduran diri.

\section{METODE PENELITIAN}

Structural Equation Modeling (SEM) merupakan gabungan dari dua metode statistik yang terpisah yaitu analisis faktor (factor analysis) yang dikembangkan dari ilmu psikologi dan psikometri serta model persamaan simultan (simultaneous equation modeling) yang dikembangkan di ekonometrika. (Ghozali, 2001), (Ghozali I. , 2011). Pada dasarnya model persamaan struktural terdiri dari dua bagian yaitu bagian pengukuran yang menghubungkan observed variabel dengan latent variabel lewat confirmatory factor model dan bagian struktur yang menghubungkan antar latent variabel lewat persamaan regresi simultan. Hair et al., (1998) mengajukan tahapan permodelan dan analisis persamaan struktural menjadi tujuh langkah yaitu :

1. Pengembangan model secara teoritis;

2. Menyusun diagram jalur (path diagram);

3. Mengubah diagram jalur menjadi persamaan struktural;

4. Memilih matrik input untuk analisa data;

5. Menilai identifikasi model;

6. Menilai kriteria Goodness of fit;

7. Interpretasi terhadap model.

Estimasi parameter dalam SEM umumnya berdasarkan pada metode Maximum Likelihood $(M L)$, menghendaki adanya asumsi yang harus dipenuhi yaitu :

- Jumlah sample harus besar. Jumlah sampel yang besar sangat kritis untuk mendapatkan estimasi parameter yang tepat, jumlah yang disarankan adalah lebih dari 100 atau minimal 5 kali jumlah observasi;

- Distribusi dari observed variabel normal secara multivariate. Analisa SEM juga menghendaki distribusi variabel harus multivariate normal sebagai konsekuensi dari asumsi sample besar (asymptotic) dan pengunaan metode estimasi $\mathrm{ML}$;

- Model yang dihipotesakan harus valid;

- Skala pengukuran variabel kontinyu (interval). Goodness of fit mengukur kesesuaian input observasi atau sesungguhnya (matrik kovarian atau korelasi) dengan prediksi dari model yang diajukan (proposed model). Dalam analisis faktor konfirmatori, prosentase rata-rata nilai Variance Extracted (AVE) antar item atau indikator suatu set konstruk laten yang merupakan ringkasan convergen indikator. AVE dapat dihitung dengan menggunakan nilai standardized loading dengan rumus sebagai berikut:

$$
A V E=\frac{\sum_{i=1}^{n} \lambda i^{2}}{\sum_{i=1}^{n} \lambda i^{2}+\sum_{i=1}^{n} \operatorname{Var}(\mathcal{E} i)}
$$

Keterangan :
AVE = Nilai Variance Extracted
$\lambda \mathrm{i}^{2}=$ Total kuadrat standardized factor loading (squared multiple correlation) untuk tiap indikator yang diperoleh dari AMOS
- $\operatorname{Var}(\varepsilon \mathrm{i})$ = Varians error dari tiap indikator. 
Nilai AVE sama dengan atau lebih dari 0,50 menunjukan adanya convergent yang baik.

Uji reliabilitas digunakan untuk menunjukan sejauh mana alat ukur yang dapat memberikan hasil yang relatif sama jika dilakukan pengukuran kembali pada obyek yang berbeda. Uji reliabilitas konstruk dalam SEM bertujuan untuk membuktikan bahwa indikator yang digunakan dapat membangun sebuah konstruk variabel, dirumuskan oleh (Ghozali I. , 2011) adalah sebagai berikut:

Keterangan:

$$
C R=\frac{\left[\sum_{i=1}^{n} \lambda i\right]^{2}}{\left[\sum_{i=1}^{n} \lambda i\right]^{2}+\left[\sum_{i=1}^{n} \delta i\right]}
$$

- $\mathrm{CR}=$ Nilai Construct Reliability;

- $\quad \sum \lambda i^{2}=$ Total kuadrat standardized factor loading (squared multiple correlation) untuk tiap indikator yang diperoleh dari AMOS;

- $\sum \delta \mathrm{i}=$ Kesalahan pengukuran (Measurement Error).

Measurement error diperoleh dari $1-\lambda i^{2}$ (kuadrat standard loading). Nilai reliabilitas yang dapat diterima adalah $\geq 0,70$ dan reliabel sedang jika diantara 0,50-0,70.

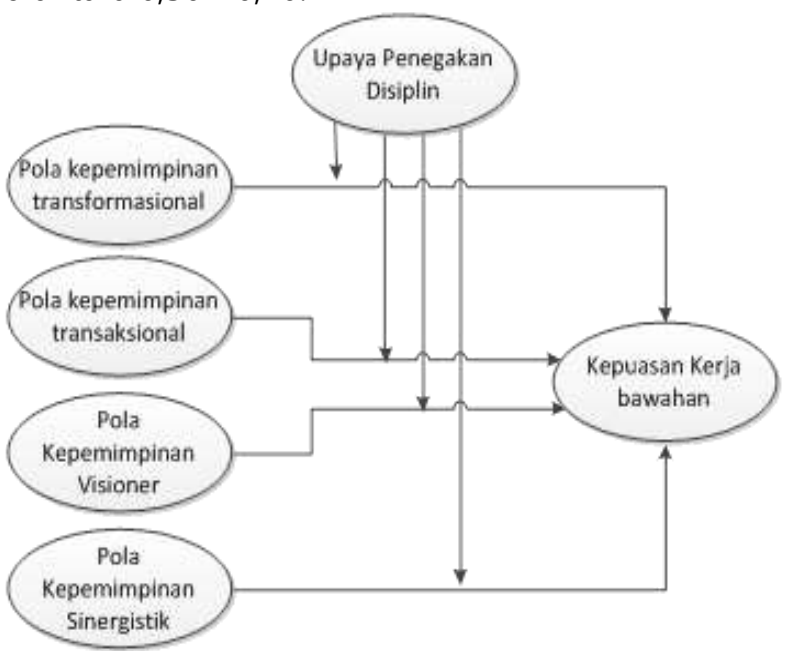

Gambar 1. Struktur Pemodelan SEM

Pembentukan model penelitian dilakukan berdasarkan tujuan penelitian dan landasan teori. Tahapan ini dimulai dengan mengidentifikasi variabel-variabel penelitian, hubungan antar variabel penelitian dan diakhiri dengan merumuskan hipotesis dari penelitian (Gambar 1). Model penelitian ini berfungsi untuk memperlihatkan hubungan yang terjadi antara variabel-variabel yang diteliti serta menggambarkan sejauh mana pola kepemimpinan dapat memberikan pengaruh terhadap kepuasan kerja bawahan. Variabel moderator yang digunakan dalam penelitian ini adalah upaya penegakan disiplin.

Variabel yang ada dalam model dapat dibedakan menjadi tiga kelompok yaitu :

1. Variabel bebas (variabel penduga). Variabel bebas merupakan variabel yang mempengaruhi variabel dependen secara positif maupun negatif. Variabel ini tidak diprediksi oleh variabel lain didalam model, terdiri atas variabel pola kepemimpinan transformasional (TF), variabel pola kepemimpinan transaksional (TR), variabel pola kepemimpinan visioner (VS), dan variabel pola kepemimpinan sinergistik (SN);

2. Variabel moderator. Variabel moderator merupakan variabel yang memiliki pengaruh kontingen yang kuat terhadap hubungan variabel independen - variabel dependen. Yang menjadi variabel dalam penelitian ini adalah upaya penegakan disiplin;

3. Variabel terikat (variabel kriteria). Variabel terikat merupakan variabel yang menjadi fokus utama peneliti. Merupakan variabel yang dipengaruhi oleh variabel sebelumnya yaitu variabel kepuasan kerja bawahan (KK).

Tabel 1. Hipotesis Penelitian

\begin{tabular}{|c|c|c|}
\hline Hipotesis 1 & & $\begin{array}{l}\text { Pola kepemimpinan transformasional } \\
\text { berpengaruh terhadap kepuasan kerja } \\
\text { bawahan }\end{array}$ \\
\hline Hipotesis 2 & & $\begin{array}{l}\text { Pola kepemimpinan transaksional } \\
\text { berpengaruh terhadap kepuasan kerja } \\
\text { bawahan }\end{array}$ \\
\hline Hipotesis 3 & & $\begin{array}{l}\text { Pola kepemimpinan visioner } \\
\text { berpengaruh terhadap kepuasan kerja } \\
\text { bawahan }\end{array}$ \\
\hline Hipotesis 4 & & $\begin{array}{l}\text { Pola kepemimpinan sinergistik } \\
\text { berpengaruh terhadap kepuasan kerja } \\
\text { bawahan }\end{array}$ \\
\hline Hipotesis 5 & & $\begin{array}{l}\text { Pola kepemimpinan transformasional } \\
\text { yang telah dimoderasi oleh upaya } \\
\text { penegakan disiplin berpengaruh } \\
\text { terhadap kepuasan kerja bawahan. }\end{array}$ \\
\hline Hipotesis 6 & & $\begin{array}{l}\text { Pola kepemimpinan transaksional yang } \\
\text { telah dimoderasi oleh upaya } \\
\text { penegakan disiplin berpengaruh } \\
\text { terhadap kepuasan kerja bawahan }\end{array}$ \\
\hline Hipotesis 7 & & $\begin{array}{l}\text { Pola kepemimpinan visioner yang telah } \\
\text { dimoderasi oleh upaya penegakan } \\
\text { disiplin berpengaruh terhadap } \\
\text { kepuasan kerja bawahan }\end{array}$ \\
\hline Hipotesis 8 & & $\begin{array}{l}\text { Pola kepemimpinan sinergistik yang } \\
\text { telah dimoderasi oleh upaya } \\
\text { penegakan disiplin berpengaruh } \\
\text { terhadap kepuasan kerja bawahan }\end{array}$ \\
\hline
\end{tabular}




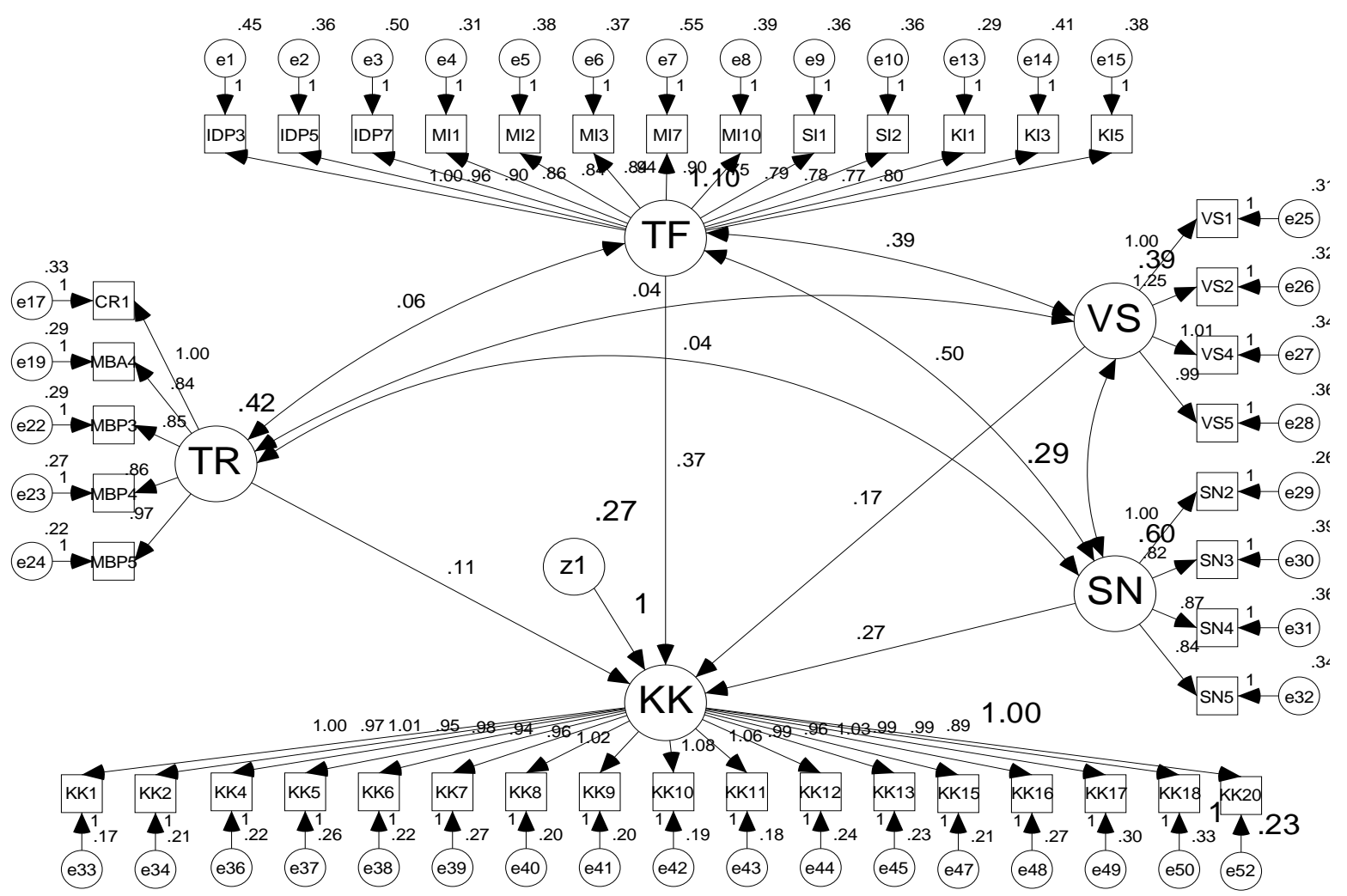

Gambar 2. Model SEM Pola Kepemimpinan TNI AL

\section{HASIL DAN PEMBAHASAN}

\section{Pengujian Asumsi Model Struktural}

Evaluasi normalitas dilakukan dengan menggunakan kriteria critical ratio skewness value sebesar $\pm 2,58$ pada tingkat signifikansi 0,01 . Data berdistribusi normal jika nilai critikal ratio skewness valuenya dibawah harga mutlak 2,58. Hasil tersebut menunjukkan bahwa secara multivariat nilai critical ratio skewness value adalah 2,141 yang berarti data normal pada tingkat signifikansi $1 \%$. Selanjutnya dilakukan evaluasi terhadap outlier dilakukan dengan memperhatikan nilai mahalanobis distance. Kriteria yang digunakan adalah berdasarkan nilai mahalanobis $d$-square, $p_{1}$ maupun $p_{2}$, nilai $p$ dibawah 0,001 adalah multivariat outlier. Dari nilai tersebut dapat diketahui bahwa tidak ada multivariate outliner. Berdasarkan hasil dari nilai Regresion weight diketahui bahwa variabel pola kepemimpinan transaksional dan pola kepemimpinan visioner tidak signifikan dalam mempengaruhi kepuasan kerja bawahan, sementara variabel yang berpengaruh terhadap kepuasan kerja bawahan adalah variabel pola kepemimpinan transformasional dan pola kepemimpinan sinergistik dengan standardized coefficient parameter TF sebesar 0,473 dan SN sebesar 0,257.

Tabel 1. Hasil Pengujian Kelayakan Full Model Struktural

\begin{tabular}{|l|c|c|c|}
\hline \multicolumn{1}{|c|}{ Goodness of fit } & Cut & Hasil & Evaluasi \\
\hline Chi-Square & Kecil & 890,326 & Fit \\
\hline Probability & $\geq$ & 0,164 & Fit \\
\hline Cmin/df & $\leq 2$ & 1,074 & Fit \\
\hline GFI & $\geq$ & 0,845 & Marginal \\
\hline RMSEA & $\leq 0.08$ & 0,015 & Fit \\
\hline AGFI & $\geq$ & 0,827 & Marginal \\
\hline TLI & $\geq 0.90$ & 0,994 & Fit \\
\hline
\end{tabular}

\section{Model Struktural yang Dimoderasi Upaya Penegakkan Disiplin}

Nilai standardized regression weight menunjukan loading besar pengaruh pola kepemimpinan transformasional adalah 0,509 sedangkan pola kepemimpinan sinergistik adalah 0,190. Full model struktural dengan moderasi upaya penegakan disiplin yang rendah hanya dapat menjelaskan variabel kepuasan kerja bawahan sebesar 49,7\%.

Nilai standardized regression weight upaya penegakan disiplin tinggi menunjukkan bahwa ada 3 variabel yang signifikan berpengaruh terhadap kepuasan kerja bawahan yaitu variabel pola 
kepemimpinan transformasional, transaksional dan sinergistik, sedangkan variabel pola kepemimpinan visioner tidak berpengaruh secara signifikan. Nilai koefisien parameter pola kepemimpinan transformasional adalah 0,427, transaksional 0,164 dan sinergistik 0,389. Variabel kepuasan kerja dapat dijelaskan sebesar $66,2 \%$. Hal ini menunjukan bahwa variabel upaya penegakan disiplin merupakan variabel moderator dalam menganalisis pengaruh pola kepemimpinan terhadap kepuasan kerja bawahan.

Tabel 2. Hasil Pengujian Full Model dengan Variabel Upaya Penegakan Disiplin

\begin{tabular}{|l|c|c|c|}
\hline Goodness of & Cut & Hasil & Evaluasi \\
\hline Chi-Square & Kecil & 2063,431 & Marginal \\
\hline Probability & $\geq 0.05$ & 0,000 & Marginal \\
\hline Cmin/df & $\leq 2$ & 1,214 & Fit \\
\hline GFI & $\geq 0.90$ & 0,716 & Marginal \\
\hline RMSEA & $\leq 0.08$ & 0,032 & Fit \\
\hline AGFI & $\geq 0.90$ & 0,684 & Marginal \\
\hline TLI & $\geq 0.90$ & 0,949 & Fit \\
\hline
\end{tabular}

Tabel 3. Rangkuman Hasil Hipotesis dan Nilai Koefisien Parameter

\begin{tabular}{|l|l|c|}
\hline & \multicolumn{1}{|c|}{ Hipotesis } & Penerimaan \\
\hline H1 & $\begin{array}{l}\text { Pola kepemimpinan } \\
\text { transformasional berpengaruh } \\
\text { terhadap kepuasan kerja } \\
\text { bawahan. }\end{array}$ & Diterima \\
\hline H2 & $\begin{array}{l}\text { Pola kepemimpinan } \\
\text { transaksional berpengaruh } \\
\text { terhadap kepuasan kerja } \\
\text { bawahan. }\end{array}$ & Ditolak \\
\hline H3 & $\begin{array}{l}\text { Pola kepemimpinan visioner } \\
\text { berpengaruh terhadap kepuasan } \\
\text { kerja bawahan. }\end{array}$ & Ditolak \\
\hline H4 & $\begin{array}{l}\text { Pola kepemimpinan sinergistik } \\
\text { berpengaruh terhadap kepuasan } \\
\text { kerja bawahan. }\end{array}$ & Diterima \\
\hline H5 & $\begin{array}{l}\text { Pola kepemimpinan } \\
\text { transformasional yang telah } \\
\text { dimoderasi oleh upaya } \\
\text { penegakan disiplin berpengaruh } \\
\text { terhadap kepuasan kerja } \\
\text { bawahan. }\end{array}$ & $\begin{array}{l}\text { Diterima } \\
\text { H7 }\end{array}$ \\
\hline $\begin{array}{l}\text { Pola kepemimpinan } \\
\text { transaksional yang telah } \\
\text { dimoderasi oleh upaya } \\
\text { penegakan disiplin berpengaruh } \\
\text { terhadap kepuasan kerja } \\
\text { bawahan. }\end{array}$ & $\begin{array}{l}\text { Pola kepemimpinan visioner } \\
\text { yang telah dimoderasi oleh } \\
\text { upaya penegakan disiplin } \\
\text { kerpengaruh terhadap kepuasan }\end{array}$ & Diterima \\
\hline
\end{tabular}

\begin{tabular}{|l|l|c|}
\hline & \multicolumn{1}{|c|}{ Hipotesis } & Penerimaan \\
\hline H8 & $\begin{array}{l}\text { Pola kepemimpinan sinergistik } \\
\text { yang telah dimoderasi oleh } \\
\text { upaya penegakan disiplin } \\
\text { berpengaruh terhadap kepuasan } \\
\text { kerja bawahan. }\end{array}$ & Diterima \\
\hline
\end{tabular}

Proses Struktural Equation Modeling TF, TR, VS dan SN terhadap KK tanpa memasukkan variabel Upaya penegakan disiplin menghasilkan persamaan berikut :

$$
\mathrm{KK}=0,473 \mathrm{TF}+0,257 \mathrm{SN}+\mathrm{Z} 1_{\text {error }}
$$

Hasil tersebut memungkinkan pemimpin untuk mengkombinasi pola kepemimpinan yang dijalankannya. Sesuai rumus tersebut porsi yang terbesar sebaiknya diberikan kepada pola kepemimpian transformasional. Sedangkan hasil dari struktural equation modeling yang telah memasukan variabel moderator adalah sebagai berikut:

$$
\mathrm{KK}=0,427 \mathrm{TF}+0,164 \mathrm{TR}+0,389 \mathrm{SN}+\mathrm{Z} 1_{\text {error }}
$$

\section{KESIMPULAN}

Berdasarkan hasil pengolahan dan analisis data yang telah dilakukan, diperoleh Pengaruh pola kepemimpinan transaksional dan pola kepemimpinan visioner terhadap kepuasan kerja bawahan adalah tidak signifikan. Artinya kepuasan kerja bawahan tidak dapat ditingkatkan hanya dengan menerapkan kedua pola kepemimpinan tersebut. Pola kepemimpinan tansformasional dan sinergistik memberikan pengaruh yang signifikan terhadap kepuasan kerja di dalam organisasi. Artinya, jika ingin meningkatkan kepuasan kerja bawahan pola kepemimpinan transformasional dan sinergistik perlu dijalankan.

Sedangkan pengaruh pola kepemimpinan terhadap kepuasan kerja bawahan setelah dimoderasi oleh upaya penegakan disiplin, bahwa pola kepemimpinan visioner yang telah dimoderasi oleh upaya penegakan disiplin tetap tidak memberikan pengaruh yang signifikan terhadap kepuasan kerja bawahan. Pola kepemimpinan transformasional, pola kepemimpinan transaksional dan pola kepemimpinan sinergistik yang telah dimoderasi oleh upaya penegakan disiplin memberikan pengaruh yang signifikan terhadap kepuasan kerja di dalam organisasi. Artinya, jika ingin meningkatkan kepuasan kerja bawahan pola kepemimpinan transformasional, pola kepemimpinan transaksional Pola kepemimpinan sinergistik perlu dijalankan bersamaan dengan 
penerapan upaya penegakan disiplin. Pola kepemimpinan yang berpengaruh paling besar adalah pola kepemimpinan transformasional. Jika menerapkan upaya penegakan disiplin maka pengaruh pola kepemimpinan transformasional akan menurun namun pengaruh pola kepemimpinan sinergistik akan meningkat dan pola kepemimpinan transaksional akan memberikan pengaruh yang signifikan.

Saran yang dapat diberikan dalam penelitian ini adalah, sebaiknya pihak pimpinan dalam Organisasi menerapkan pola kepemimpinan tranformasional dan sinergistik sesuai dengan proporsi dalam persamaan dalam meningkatkan kepuasan kerja bawahan. Jika menerpakan upaya penegakan disiplin maka perlu ditambahkan dengan pola kepemimpinan transaksional. Dalam melaksanakan tugas-tugasnya, pihak staf organisasi sebaiknya tidak hanya terfokus pada pelaksanaan tugas pokok, namun juga memperhatikan faktor kepuasan kerja bawahan. Hal ini perlu diperhatikan karena dalam kondisi lingkungan kerja yang disiplin, kepuasan kerja bawahan lebih sulit untuk dipenuhi dibandingkan organisasi-organisasi lain yang lingkungan kerjanya lebih santai. Saran untuk penelitian selanjutnya adalah perlu adanya penelitian lanjutan dalam organisasi sejenis untuk melihat pengaruh pola kepemimpinan terhadap kepuasan kerja bawahan, dengan harapan agar tingkat kepuasan kerja di organisasi-organisasi tersebut dapat diketahui beserta faktor-faktor yang mempengaruhinya sehingga dapat dijadikan masukan bagi pihak pimpinan untuk meningkatkan kepuasan kerja bawahan.

\section{DAFTAR PUSTAKA}

DeCenzo, D., \& Robbins, S. (2010). Fundamentals of Human Resource Management, 10th Edition. . New Jersey: John Wiley \& Sons, Inc.

Ghozali, I. (2001). Aplikasi Analisis Multivariate Dengan SPSS. Semarang: BPFE Undip.

Ghozali, I. (2011). Aplikasi Analisis Multivariate Dengan Program IBM SPSS 19 (Edisi Kelima). Semarang : Universitas Diponegoro.
Hair, J. F., Anderson, R., Tatham, R., \& Black, W. (1998). Multivariate Data Analysis, 6th edition. Upper Saddle: Prentice Hall International, Inc. .

Hartanto, R. D. (2012). Pengaruh Komunikasi,Kepemimpinan dan Budaya Organisasi terhadap Kinerja karyawan Pada PDAM Kabupaten Demak. Semarang: Fakultas Ekonomi Universitas Stikubank.

Hayati, E., \& Faisal, S. M. (2018). Faktor-faktor yang mempengaruhi kepuasan kerja dan dampaknya terhadap kinerja pegawai Kanwil Direktorat Jenderal Kekayaan Negara Aceh Volume 2 No 1. Jurnal Magister Manajemen.

Hicks, H. G., \& Gullet, G. R. (1996). Organisasi Teori dan Tingkah Laku. Jakarta: Bumi Aksara.

Robbins, S. P. (2003). Perilaku Organisasi: Konsep Kontroversi Aplikasi. Edisi Kedelapan. Translate by Pujaatmaka, H \& Molan, B. Jakarta: PT. Prenlindo.

Robbins, S., \& Judge, T. (2013). Organizational Behavior, 15th edition. . New Jersey: Pearson Education Inc.

Smith, C., Organ, D., \& Near, J. (1983). Organizational Citizenship Behavior: Its Nature and Antecedents. Journal of Applied Psychology, Vol 68, No 4, 653-663.

Strauss, \& Sayles. (1980). Personnel - The Human Problems of Managements. 4th edition. . New Jersey, USA: Prentice - Hall.

Weiss, D. J., Dawis, R. V., England, G. W., \& Lofquist, L. H. (1967). Manual for the Minnesota Satisfaction Questionnaire. Vol. 22, Minnesota Studies in Vocational Rehabilitation. Minneapolis: University of Minnesota, Industrial Relations Center.

Weiss, H., \& Cropanzano, R. (1996). Affective Events Theory: A Theoritical Discussion of The Structure, Causes, and Consequences of Affective Experiences At Work. . Research in Organizational Behavior Vol 18, 1-74. 